\title{
Educational Processes for Health and Disease Self-Management in Public Health: A Systematic Review
}

\author{
Jessica Alejandra Ruiz-Ramírez ${ }^{1, *(1)}$, Yury Arenis Olarte-Arias ${ }^{2}$ and Leonardo David Glasserman-Morales ${ }^{1}$ (D) \\ 1 School of Humanities and Education, Tecnologico de Monterrey, Monterrey 64849, Mexico; \\ glasserman@tec.mx \\ 2 Research Department, Escuela Colombiana de Rehabilitación, Bogota 111321, Colombia; \\ yury.olarte@ecr.edu.co \\ * Correspondence: alejandra.ruiz.rz@gmail.com
}

check for

updates

Citation: Ruiz-Ramírez, J.A.;

Olarte-Arias, Y.A.;

Glasserman-Morales, L.D.

Educational Processes for Health and Disease Self-Management in Public Health: A Systematic Review. Int. J. Environ. Res. Public Health 2021, 18 6448. https://doi.org/10.3390/ ijerph18126448

Academic Editor: Paul B. Tchounwou

Received: 26 May 2021

Accepted: 11 June 2021

Published: 15 June 2021

Publisher's Note: MDPI stays neutral with regard to jurisdictional claims in published maps and institutional affiliations.

Copyright: (c) 2021 by the authors. Licensee MDPI, Basel, Switzerland. This article is an open access article distributed under the terms and conditions of the Creative Commons Attribution (CC BY) license (https:// creativecommons.org/licenses/by/ $4.0 /)$

\begin{abstract}
This study systematically reviewed processes and educational programs for self-management of health and diseases that are the subject of public health attention. This systematic review of the literature (SRL) is relevant to recognizing the characteristics of the educational processes in self-managing chronic diseases in contexts where technology did not play a significant role. Following the PRISMA protocol, the authors independently reviewed full-text articles from several databases using the following criteria: (1) intervention studies evaluating the effects of self-management health programs; (2) educational process of disease self-management; (3) studies that included at least one control group, and (4) peer-reviewed studies. In addition, the Scottish Intercollegiate Guideline Network measurement tool was used to assess the risk of bias in each trial. In the final sample, 38 articles were included. The findings regarding health education methods of self-care, using community-based care and technological tools, are considered fundamental. Among the conclusions, the relevance of the pedagogy that health education processes demand improvement in post-pandemic program effectiveness stands out.
\end{abstract}

Keywords: self-management of health; educational processes; self-management of diseases; innovative education; higher education

\section{Introduction}

Educational processes in public health seek to ensure the populations' right to health by promoting improved living conditions, welfare, and development [1]. Public health education programs address healthcare-related challenges caused by (often chronic) diseases; and they focus on socially and economically vulnerable populations [2]. They also promote healthy lifestyles through nutrition and mental, sexual, and reproductive health. Similarly, medical and health education processes are mainly organized around disease prevention and health promotion training programs. Their common purpose is to facilitate knowledge generation and develop skills necessary for the self-care and self-management of diseases [3]. Likewise, training programs are focused, on the one hand, on health education programs, i.e., actions and activities focused on providing information to individuals and groups to encourage the promotion, maintenance, and restoration of health, and, on the other hand, on medical education programs, which aim to promote the training of physicians and other health professionals for participation in health education contexts, including those required in public healthcare.

Health education interventions have traditionally focused on prescriptions and lifestyle restrictions [4]. This approach is a passive transfer of theoretical knowledge, but lacks feedback and does not always consider the realities of communities [5]. Therefore, health authorities have had to make great efforts to facilitate access to medical and health education, considering that educational processes optimize medical treatment results and the prevention of the development of diseases or problems that affect people's quality of life [6]. Such actions align with the World Health Organization (WHO) recommendations, 
which state that "quality of life refers to a person's perception of his or her life situation concerning the culture and value system of society, as well as its relationship to goals, expectations, standards and needs" ([7], p. 3).

Therefore, educational actions developed in public health contexts and reported by research mainly focus on disease self-management and the appropriation of self-care skills [8]. Medical and health education literature primarily verify the numerous challenges people with diseases or public health problems face in daily self-care activities. This suggests the need for ongoing support to navigate the self-care process, seeking to manage the personal, environmental, and economic factors that challenge disease management in everyday contexts [9]. Therefore, experts suggest that health care should include routine medical treatment and health education to maintain comprehensive wellness [10]. Thus, the educational processes should include addressing the challenges that affect the quality of life and motivation to develop self-care activities and controlling the physical symptoms of disease [11].

Access to medical and health education programs include mechanisms to counteract their low participation rates. According to health institutions and research worldwide, low community participation is mainly related to socioeconomic conditions, transition effects over time, and a low level of health experts in educational training [12]. Additionally, some barriers to health education program effectiveness were accentuated and diversified due to health conditions caused by the COVID-19 pandemic. Health conditions that, in turn, have made visible and deepened economic, social, and cultural factors associated with inequality, limiting access to social and health services, and health education.

The importance of working on the aspects that affect people's willingness to participate in educational programs and daily, personal, collective activities to control and treat disease is evident. In this regard, improving self-regulation and self-management requires immediate feedback to modify behavior [13]. Thus, the concept of self-management emerges in health systems in the migration of the orientation from treatment to health promotion and maintenance [14].

Likewise, health education programs have various innovative educational strategies that focus on the subject and his/her context to facilitate the formative effectiveness of the programs [15]. Education to preserve and promote health is the initial approach implemented at generalized and diverse societal levels to change habits and routines [16]. Subsequently, different community participatory approaches have been incorporated into medical and health education processes. These allow people to have a voice to elucidate barriers, facilitating self-management of health and health information needs, and thus encouraging communities to take on active roles in the educational process, even supporting the design of activities [17].

Other health education initiatives have reflected on the role of health education professionals to ensure that there are no gaps in access to educational programs [18]. Furthermore, it is considered that the training processes of health professionals should be continuous and cover not only the clinical or physical aspects, but also the psychosocial aspects of a population [19]. In this regard, health education should be provided holistically by various professionals who have both updated knowledge and adequate skills. Further, health education programs have involved the use of technologies to increase the effectiveness of these programs. Information and communication technologies are powerful tools for promoting the quality and efficiency of education. They have helped migrate knowledge in education to transform traditional educational methods used in the health field [20]. Thus, web-based applications and technologies are making inroads as health education tools for self-management, self-care, and control of diseases to improve the quality of life of individuals. In addition, ICTs provide valuable tools for accessing information and improving the appropriation of health-related knowledge [21].

Educational approaches involving technological tools in training processes in healthcare are in an exploratory phase, given the possibilities of improvement offered by technology [22]. This systematic review of the literature is relevant to recognizing the charac- 
teristics of the educational processes in self-managing chronic diseases in contexts where technology did not play a significant role. This research will contribute to educational methodologies in public health for a new vision of implementing educational technologies in a post-pandemic context. Therefore, this article helps expand the theoretical corpus on the characteristics of innovative educational processes to self-manage health in public healthcare. The first section of this article describes the methodological strategy used in the research based on a systematic literature review, while the second presents our findings, analysis, and interpretation. Finally, the third section contains discussions on the following question: what are the characteristics of the educational processes of self-management of health in public health care?

\section{Materials and Methods}

\subsection{Literature Search}

This systematic review was conducted according to the preferred reporting items for systematic reviews and meta-analyses, or PRISMA, guidelines [23]. To identify potentially relevant papers, we searched the following bibliographic databases: Scopus and Web of Science (WoS). Articles from peer-reviewed journals were included if they were published between 2006 and 2020, written in English, and available via open access to use information and communication technologies (ICTs) to increase and improve the dissemination of knowledge. Open access refers to freedom, flexibility, and impartiality [24]. Furthermore, quantitative, qualitative, and mixed methods studies were included to consider different aspects of self-management health education programs. Finally, articles that did not fit the study's conceptual framework were excluded, for example, research developed within a pandemic context.

\subsection{Selection Criteria}

One author performed the initial eligibility assessment by reviewing the titles and abstracts. Then, two authors independently reviewed full-text versions of 92 articles using the following criteria: (1) intervention studies evaluating the effects of self-management health programs; (2) studies including at least one control group; and (3) peer-reviewed studies.

\subsection{Data Extraction}

Data extraction was performed independently by the authors. The following data were extracted from each study: first author, date and place of publication, study design, population served, analysis of the program effectiveness, EdTech used, and pedagogical strategy. Extracted data were entered into standardized MS Excel files. Any disagreements were resolved by discussion among the authors.

\subsection{Quality Assessment Tool}

The Scottish Intercollegiate Guideline Network (SIGN) measurement tool was used to assess the risk of bias in each study in this review. SIGN was developed in 1993 to improve healthcare quality for populations in Scotland by reducing variation in practice and outcomes by developing and disseminating national clinical guidelines with recommendations for effective practice based on current evidence [25]. This tool suggests the use of risk of bias domains, and so, a set of key considerations was used. These considerations sought to prompt and guide assessors to consider potentially relevant issues when conducting their assessment for a risk of bias domain. Using SIGN, we assessed the study's internal validity and risk of bias. We assigned values of "high quality $(++)$ ", "acceptable $(+)$ ", "low quality $(-)$ ", or "unacceptable: rejection (0)" to each study. The rating (0) enabled assessors to indicate that the information required to rate risk of bias was either not reported at all, or reported too incompletely to rate risk of bias with sufficient confidence. The risk of bias was assessed independently by the reviewers and a consensus process resolved any disagreement. 


\section{Results}

\subsection{Identification and Selection of Studies}

A total of 3114 records were found in the database search. These search results were imported using Parsifal, and 1428 duplicates and 81 records marked as ineligible by automation tools were removed. A detailed flow chart of the selection process is shown in Figure 1.

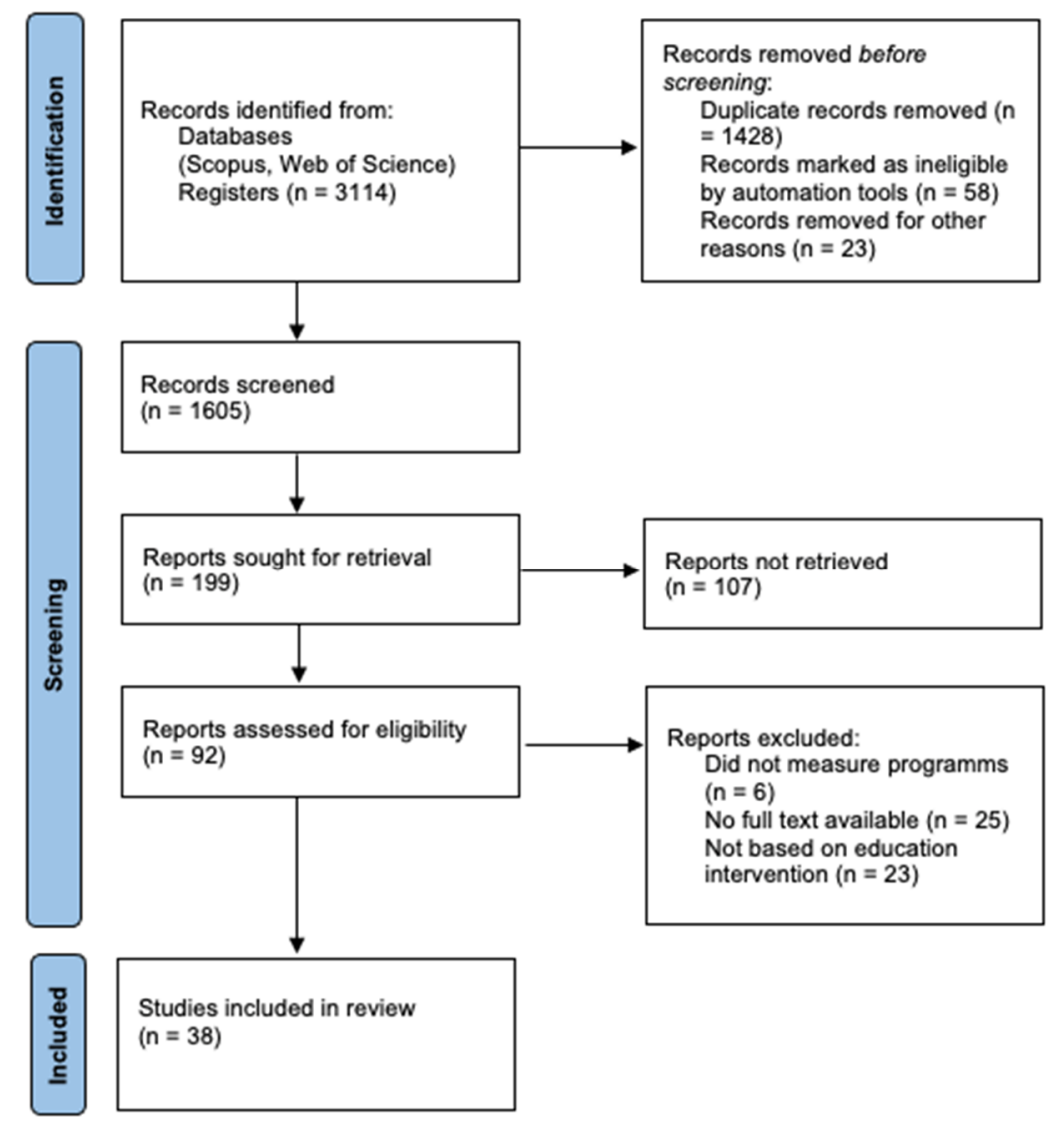

Figure 1. Flow diagram of the screening process for systematic reviews and meta-analyses (PRISMA).

After the elimination of duplicates, 1605 records were examined. Subsequently, we searched for papers citing any of the initially included studies. However, no additional articles meeting the inclusion criteria were found in these searches. Finally, 38 full-text papers were reviewed.

\subsection{Characteristics of the Study}

It was identified that, while some articles met the inclusion criteria, they evaluated performances in regular professional training processes in health [26,27], leaving aside the analysis of teaching-learning processes in public health contexts. For this reason, they were excluded from the analysis. The research was conducted across five continents: Europe $(n=14)$, Asia $(n=13)$, North America $(n=8)$, Africa $(n=3)$, and Oceania (1). Twenty-five studies involved adults aged between 35 and 60 years, while ten studies reported educational programs for self-management of health and disease with young adult participants between 18 and 35 . In a smaller proportion, programs involving follow-up and control of people $>65$ years $(n=2)$ and accompanied by health professionals $(n=2)$ were identified. The general characteristics of the studies are presented in Table 1. 
Table 1. General characteristics of the included studies $(n=38)$.

\begin{tabular}{|c|c|c|c|}
\hline Variables & Categories & $n$ & $\%$ \\
\hline \multirow{4}{*}{ Evaluation of the self-management program } & Statistical analysis & 18 & $(47.3)$ \\
\hline & Multidisciplinary teams & 15 & $(39.4)$ \\
\hline & Perception analysis & 3 & $(7.8)$ \\
\hline & Expert analysis & 2 & $(5.2)$ \\
\hline \multirow{7}{*}{ Study design } & Controlled trial & 20 & $(52.6)$ \\
\hline & Qualitative & 9 & $(23.6)$ \\
\hline & Observational study & 5 & (13.1) \\
\hline & Community clinic & 1 & $(2.6)$ \\
\hline & Study of parallel groups & 1 & (2.6) \\
\hline & Mixed type research & 1 & $(2.6)$ \\
\hline & Grounded theory & 1 & (2.6) \\
\hline \multirow{12}{*}{ Diseases } & Diabetes mellitus type 2 & 12 & $(31.6)$ \\
\hline & Chronic diseases & 9 & $(23.7)$ \\
\hline & Type 1 diabetes & 7 & $(18.4)$ \\
\hline & Cancer & 2 & $(5.3)$ \\
\hline & Diabetes and acute coronary syndrome & 1 & $(2.6)$ \\
\hline & Epilepsy & 1 & (2.6) \\
\hline & Maternal Stress & 1 & $(2.6)$ \\
\hline & Hypertension & 1 & $(2.6)$ \\
\hline & Obesity & 1 & $(2.6)$ \\
\hline & Osteoarthritis & 1 & $(2.6)$ \\
\hline & Metabolic syndrome (MetS) & 1 & $(2.6)$ \\
\hline & HIV and tuberculosis & 1 & $(2.6)$ \\
\hline
\end{tabular}

Table 2 contains a summary of the research included in this review, including information on the variables: author, year, country of study development, study design, population served, analysis of program effectiveness, tools, technologies used, and pedagogical strategy. The selected studies were published between 2016 and 2020.

Table 2. Summary of included research.

\begin{tabular}{|c|c|c|c|c|c|c|}
\hline Author, Year & $\begin{array}{l}\text { Country of Study } \\
\text { Development }\end{array}$ & Study Design & Population Served & $\begin{array}{l}\text { Analysis of the } \\
\text { Program } \\
\text { Effectiveness }\end{array}$ & EdTech Used & $\begin{array}{l}\text { Pedagogical } \\
\text { Strategy }\end{array}$ \\
\hline Woods (2019) [28] & South Africa & Study observational & $\begin{array}{l}\text { Health } \\
\text { professionals }\end{array}$ & Statistical analysis & WhatsApp & $\begin{array}{c}\text { Exchange and } \\
\text { discussion of critical } \\
\text { clinical cases } \\
\text { through a social } \\
\text { networking } \\
\text { platform }\end{array}$ \\
\hline Zimbudzi (2019) [29] & Australia & Theory & Adult patients & $\begin{array}{c}\text { Equipment } \\
\text { multidisciplinary }\end{array}$ & $\begin{array}{l}\text { DVD, websites, } \\
\text { telephone } \\
\text { support }\end{array}$ & $\begin{array}{l}\text { Design-based } \\
\text { research (DBR) to } \\
\text { develop an } \\
\text { educational } \\
\text { resource }\end{array}$ \\
\hline Risica (2018) [30] & United States & Community clinic & Hispanic adults & Statistical analysis & Without mention & $\begin{array}{l}\text { Intervention } \\
\text { program called Vida } \\
\text { Sana Program }\end{array}$ \\
\hline McElfish (2019) [31] & United States & Controlled trial & Adult patients & Statistical analysis & Without mention & $\begin{array}{l}\text { DSME (diabetes } \\
\text { self-management } \\
\text { education) } \\
\text { methodology }\end{array}$ \\
\hline Patel (2019) [32] & England & Controlled trial & Adult patients & Perception analysis & Without mention & $\begin{array}{c}\text { COPERS } \\
\text { methodology } \\
\text { (Coping with } \\
\text { Persistent Pain, } \\
\text { Effectiveness, } \\
\text { Research into } \\
\text { Self-management). }\end{array}$ \\
\hline
\end{tabular}


Table 2. Cont.

\begin{tabular}{|c|c|c|c|c|c|c|}
\hline Author, Year & $\begin{array}{l}\text { Country of Study } \\
\text { Development }\end{array}$ & Study Design & Population Served & $\begin{array}{l}\text { Analysis of the } \\
\text { Program } \\
\text { Effectiveness }\end{array}$ & EdTech Used & $\begin{array}{l}\text { Pedagogical } \\
\text { Strategy }\end{array}$ \\
\hline Hailu (2019) [33] & Ethiopia & Controlled trial & Adult patients & Statistical analysis & Without mention & $\begin{array}{l}\text { DSME (diabetes } \\
\text { self-management } \\
\text { education) } \\
\text { methodology }\end{array}$ \\
\hline Pal (2018) [34] & England & Qualitative & Adult patients & $\begin{array}{c}\text { Equipment } \\
\text { multidisciplinary }\end{array}$ & $\begin{array}{l}\text { Digital health } \\
\text { interventions } \\
\text { (DHI) }\end{array}$ & $\begin{array}{l}\text { DSME (diabetes } \\
\text { self-management } \\
\text { education) } \\
\text { methodology }\end{array}$ \\
\hline Azami (2018) [35] & Iran & Controlled trial & Adult patients & Statistical analysis & Without mention & $\begin{array}{c}\text { Professional } \\
\text { accompaniment }\end{array}$ \\
\hline Lee (2019) [36] & Korea & Controlled trial & Adult patients & $\begin{array}{c}\text { Equipment } \\
\text { multidisciplinary }\end{array}$ & Without mention & $\begin{array}{c}\text { Professional } \\
\text { accompaniment }\end{array}$ \\
\hline Omidi (2020) [37] & Iran & Controlled trial & Adults-women & Statistical analysis & Social networks & $\begin{array}{l}\text { Technology- } \\
\text { mediated } \\
\text { professional } \\
\text { accompaniment }\end{array}$ \\
\hline Ji (2019) [7] & China & Controlled trial & Adult patients & Statistical analysis & Without mention & $\begin{array}{l}\text { DSME (diabetes } \\
\text { self-management } \\
\text { education) } \\
\text { methodology }\end{array}$ \\
\hline Farahmand (2019) [38] & Iran & Controlled trial & Senior citizens & Statistical analysis & Without mention & $\begin{array}{c}\text { Professional } \\
\text { accompaniment }\end{array}$ \\
\hline Prevost (2019) [39] & France & Controlled trial & Adult patients & Statistical analysis & Without mention & $\begin{array}{l}\text { TPE (Therapeutic } \\
\text { Patient Education) } \\
\text { methodology }\end{array}$ \\
\hline Boels (2018) [40] & Netherlands & Controlled trial & Adult patients & Statistical analysis & Smartphone app & $\begin{array}{c}\text { Monitoring } \\
\text { mediated by } \\
\text { technological tools }\end{array}$ \\
\hline Zheng (2019) [41] & China & Controlled trial & Adult patients & Statistical analysis & Without mention & $\begin{array}{c}\text { Professional } \\
\text { accompaniment }\end{array}$ \\
\hline Jinnouchi (2019) [42] & Japan & $\begin{array}{l}\text { Study of parallel } \\
\text { groups }\end{array}$ & Adult patients & Statistical analysis & Without mention & $\begin{array}{l}\text { Use of educational } \\
\text { materials: books } \\
\text { and DVDs }\end{array}$ \\
\hline Smith (2018) [43] & United States & Controlled trial & Adults-men & Statistical analysis & Without mention & $\begin{array}{c}\text { Chronic Disease } \\
\text { Self-Management } \\
\text { Education (CDSME) } \\
\text { program }\end{array}$ \\
\hline Kennedy (2019) [44] & United States & Controlled trial & Adults-women & Statistical analysis & Without mention & $\begin{array}{c}\text { Participation in } \\
\text { collaborative } \\
\text { groups }\end{array}$ \\
\hline Pozza (2020) [45] & Italy & Controlled trial & Adult patients & Statistical analysis & Without mention & $\begin{array}{l}\text { Analysis using } \\
\text { questionnaire } \\
\text { results }\end{array}$ \\
\hline Sanders (2018) [46] & England & Qualitative & Young adults & $\begin{array}{c}\text { Equipment } \\
\text { multidisciplinary }\end{array}$ & Without mention & $\begin{array}{c}\text { Educational } \\
\text { intervention: } \\
\text { 'WICKED' (Working } \\
\text { with Insulin, } \\
\text { Carbohydrates, } \\
\text { Ketones and } \\
\text { Exercise to Control } \\
\text { Diabetes) }\end{array}$ \\
\hline Ross (2019) [47] & England & Qualitative & Adult patients & $\begin{array}{c}\text { Equipment } \\
\text { multidisciplinary }\end{array}$ & Websites & $\begin{array}{l}\text { DSME (diabetes } \\
\text { self-management } \\
\text { education) } \\
\text { methodology }\end{array}$ \\
\hline Gagliardino (2019) [6] & Middle East & $\begin{array}{c}\text { Study } \\
\text { Observational }\end{array}$ & Adult patients & Expert analysis & Without mention & $\begin{array}{c}\text { Analysis using } \\
\text { questionnaire } \\
\text { results }\end{array}$ \\
\hline Senteio (2018) [22] & United States & $\begin{array}{l}\text { Research mixed } \\
\text { type }\end{array}$ & Senior citizens & Perception analysis & Smartphone app & $\begin{array}{c}\text { Community-based } \\
\text { health education } \\
\text { program }\end{array}$ \\
\hline Carmienke (2020) [48] & Germany & Qualitative & Adult patients & $\begin{array}{c}\text { Equipment } \\
\text { Multidisciplinary }\end{array}$ & Without mention & $\begin{array}{l}\text { DSME (diabetes } \\
\text { self-management } \\
\text { education) } \\
\text { methodology }\end{array}$ \\
\hline Pratt (2018) [49] & United States & Controlled trial & Adult patients & Statistical analysis & Without mention & $\begin{array}{c}\text { Professional } \\
\text { accompaniment }\end{array}$ \\
\hline Siltanen (2020) [19] & Finland & Qualitative & $\begin{array}{c}\text { Health } \\
\text { professionals }\end{array}$ & Expert analysis & Without mention & $\begin{array}{c}\text { Professional } \\
\text { accompaniment }\end{array}$ \\
\hline Muchiri (2019) [9] & South Africa & Qualitative & Adult patients & Perception analysis & Without mention & $\begin{array}{l}\text { Analysis using } \\
\text { questionnaire } \\
\text { results }\end{array}$ \\
\hline
\end{tabular}


Table 2. Cont.

\begin{tabular}{|c|c|c|c|c|c|c|}
\hline Author, Year & $\begin{array}{l}\text { Country of Study } \\
\text { Development }\end{array}$ & Study Design & Population Served & $\begin{array}{l}\text { Analysis of the } \\
\text { Program } \\
\text { Effectiveness }\end{array}$ & EdTech Used & $\begin{array}{l}\text { Pedagogical } \\
\text { Strategy }\end{array}$ \\
\hline Varming (2018) [15] & Denmark & Qualitative & $\begin{array}{c}\text { Educators of health } \\
\text { programs and adult } \\
\text { patients }\end{array}$ & $\begin{array}{c}\text { Equipment } \\
\text { multidisciplinary }\end{array}$ & Without mention & $\begin{array}{c}\text { Participation in } \\
\text { collaborative } \\
\text { groups }\end{array}$ \\
\hline Jönsson (2019) [50] & Sweden & $\begin{array}{c}\text { Study } \\
\text { Observational }\end{array}$ & Adult patients & $\begin{array}{l}\text { Equipment } \\
\text { multidisciplinary }\end{array}$ & Without mention & $\begin{array}{c}\text { Participation in } \\
\text { collaborative } \\
\text { groups }\end{array}$ \\
\hline Rasoul (2019) [20] & Iran & Qualitative & Adult patients & Statistical analysis & $\begin{array}{l}\text { Internet webpage } \\
\text { and social } \\
\text { networks }\end{array}$ & $\begin{array}{c}\text { Monitoring } \\
\text { mediated by } \\
\text { technological tools }\end{array}$ \\
\hline Ridsdale (2018) [51] & United Kingdom & Controlled trial & $\begin{array}{l}\text { Adults and } \\
\text { caregivers }\end{array}$ & $\begin{array}{l}\text { Equipment } \\
\text { multidisciplinary }\end{array}$ & Without mention & $\begin{array}{l}\text { Participation in } \\
\text { collaborative } \\
\text { groups }\end{array}$ \\
\hline Chang (2019) [52] & Taiwan & Controlled trial & Adult patients & $\begin{array}{c}\text { Equipment } \\
\text { multidisciplinary }\end{array}$ & Without mention & Inverted classroom \\
\hline Davies (2019) [53] & United Kingdom & Controlled trial & Adult patients & $\begin{array}{c}\text { Equipment } \\
\text { multidisciplinary }\end{array}$ & Without mention & $\begin{array}{c}\text { Professional } \\
\text { accompaniment }\end{array}$ \\
\hline $\begin{array}{c}\text { Vandenbosch (2018) } \\
{[54]}\end{array}$ & Northern Europe & $\begin{array}{c}\text { Study } \\
\text { Observational }\end{array}$ & Adult patients & $\begin{array}{l}\text { Equipment } \\
\text { multidisciplinary }\end{array}$ & Websites & $\begin{array}{l}\text { Technology- } \\
\text { mediated } \\
\text { professional } \\
\text { accompaniment }\end{array}$ \\
\hline Liu (2018) [55] & China & $\begin{array}{c}\text { Study } \\
\text { Observational }\end{array}$ & Adult patients & Statistical analysis & WeChat app & $\begin{array}{l}\text { Technology- } \\
\text { mediated } \\
\text { professional } \\
\text { accompaniment }\end{array}$ \\
\hline Preechasuk (2019) [56] & Thailand & Qualitative & $\begin{array}{l}\text { Health } \\
\text { professionals }\end{array}$ & $\begin{array}{l}\text { Equipment } \\
\text { multidisciplinary }\end{array}$ & Without mention & $\begin{array}{c}\text { Analysis using } \\
\text { questionnaire } \\
\text { results }\end{array}$ \\
\hline Bourbeau (2018) [57] & Canada & Controlled trial & Adult patients & $\begin{array}{c}\text { Equipment } \\
\text { multidisciplinary }\end{array}$ & Websites & $\begin{array}{c}\text { Professional } \\
\text { accompaniment }\end{array}$ \\
\hline Zhao (2019) [5] & China & Controlled trial & Adult patients & $\begin{array}{l}\text { Equipment } \\
\text { multidisciplinary }\end{array}$ & Without mention & $\begin{array}{c}\text { Participation in } \\
\text { collaborative } \\
\text { groups }\end{array}$ \\
\hline
\end{tabular}

\subsubsection{Pedagogical Strategies for Disease Self-Management Programs}

Disease self-management programs link different pedagogical strategies and learning methodologies developed to contribute to the knowledge and control of chronic diseases. It was highlighted that $16 \%$ of the investigations $[7,31,33,34,47,48]$ related to using the DSME (diabetes self-management education) methodology to self-manage Type 1 and Type 2 Diabetes, focusing on glycemic control measures because of changes in glycosylated hemoglobin. Likewise, the COPERS (Coping with persistent Pain, Effectiveness, Research into Self-management) methodology [32] and the TPE (Therapeutic Patient Education) methodology [39] were used to identify the needs of patients and family members in pain management. Concerning the above, the results showed that only $21 \%$ of the research on medical and health education $[9,15,20,22,30,47,48,56]$ described educational programs or actions oriented around community-based health and appropriation of culture [6].

Similarly, methodologies that allowed discussion and knowledge exchange among patients in collaborative groups in contextual intervention programs were recognized. We also found analyses of patient perception through the accompaniment of a professional or the majoritarian use of qualitative analysis tools. Figure 2 presents the trends in methodological design. 


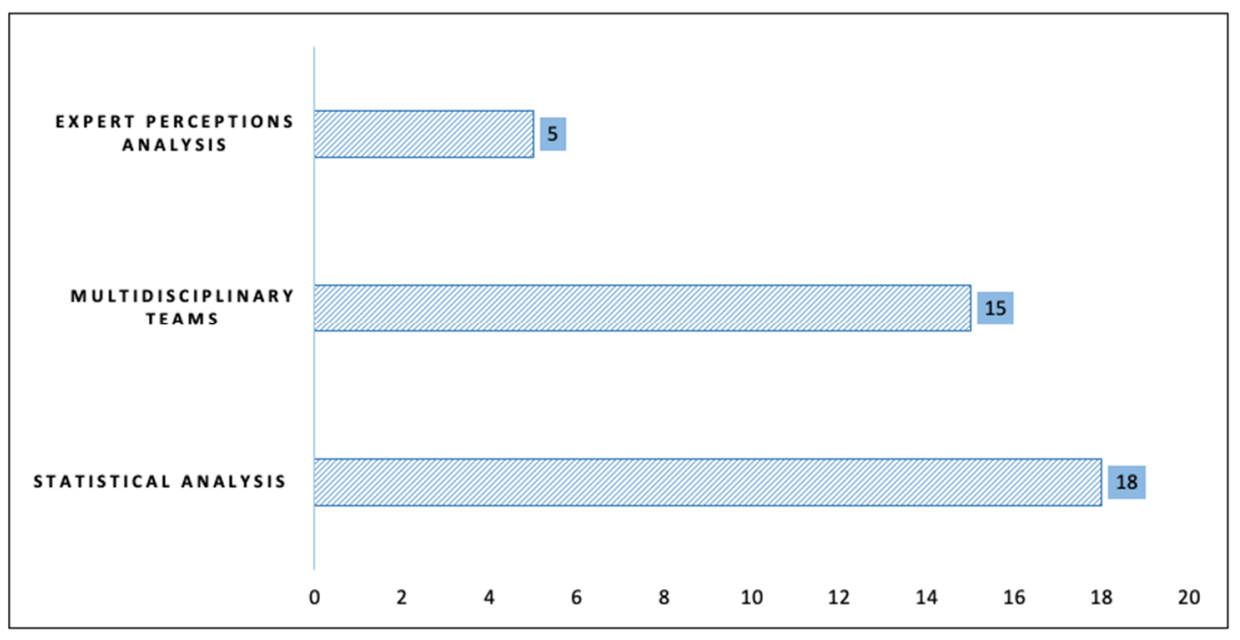

Figure 2. Methodological design.

3.2.2. EdTech to Support Educational Processes for Self-Management of Health or Self-Management of Illnesses

This review showed that $29 \%$ of the texts studied $[20,22,28,29,34,37,40,47,54,55,57]$ reported technological tools as a digital literacy alternative for people with health conditions, as well as for professionals, family members, and caregivers. Technological tools accessible to the community were identified using free applications, such as WhatsApp and WeChat, accessible via smartphone, and disseminating content through websites and social networks, defined as Digital Health Interventions (DHI).

It was emphasized that the analysis of technological tools, which contributed to selfmanagement of diseases, were contemplated where technology was not an indispensable tool for their management, as reflected in $71 \%$ of the investigations that do not report the mediation of technology in their educational process. This point becomes relevant for identifying lessons learned and best practices of current educational processes that aim to meet educational challenges during and after pandemics, where technology is the main instrument for transmitting knowledge.

\subsection{Quality Assessment}

According to the SIGN checklist, 18 of the studies $[7,20,28,30,31,33,35,37-45,49,55]$ were rated "high quality" and 17 studies were "acceptable quality" [5,6,15,19,29,34,36,46-48,50-54,56]. Although the studies were rated as being high and acceptable quality, for sample selection random assignment was used and no detailed description of the procedure was provided. Three of the studies were rated as low quality $[9,22,32]$. The main reasons for the "low quality" ratings were inadequate randomization or the method of concealment used. Among the 11 categories of the SIGN checklist, the studies were classified as "high risk of bias", particularly in two categories: "when the study is conducted at more than one site, are the results comparable for all sites?" and "how well was the study conducted to minimize bias?". These categories were identified following the results assessment by each author. Figure 3 presents the risk of bias graph. 


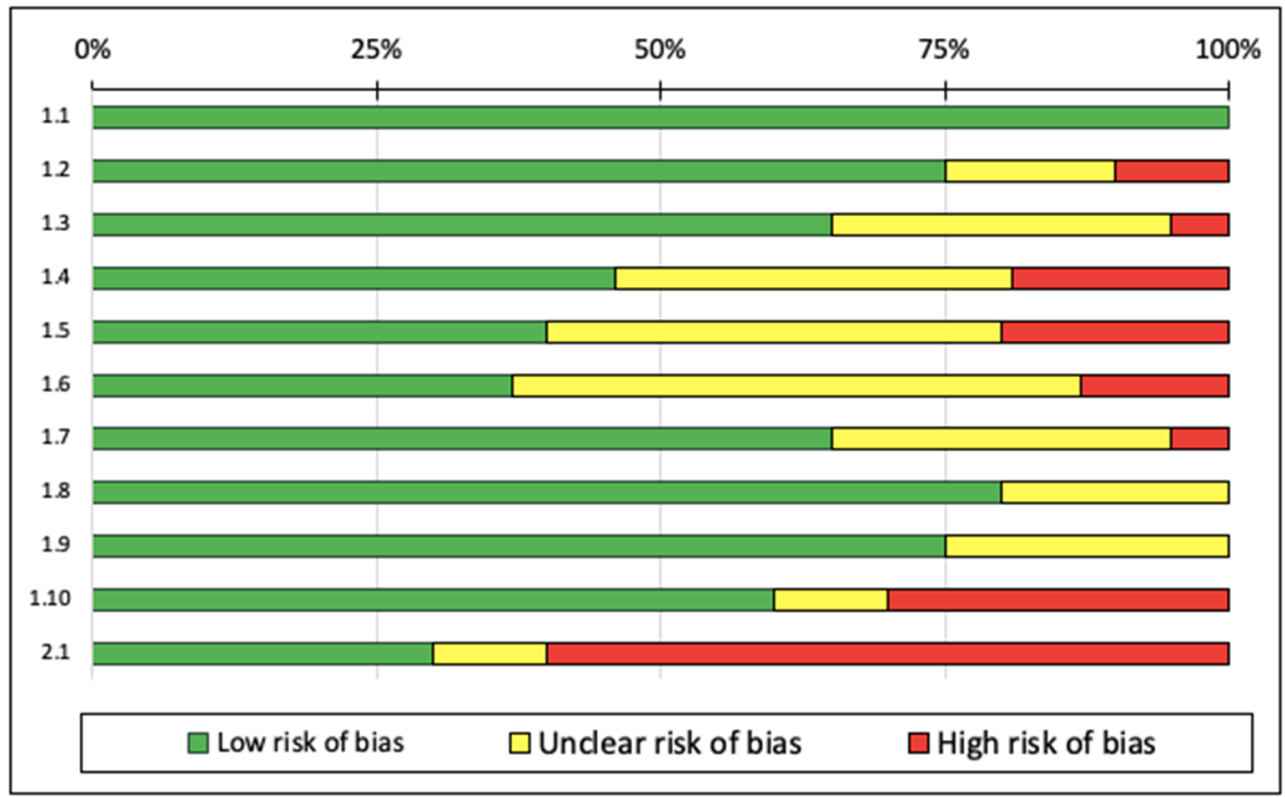

Figure 3. Risk of bias graph. Note: The authors' judgments on each element of risk of bias are presented as percentages for all included studies. (1.1) the study addresses an adequate and focused question; (1.2) the allocation of participants in the treatment group is randomized; (1.3) an adequate method of concealment is used; (1.4) the design keeps participants and investigators "blind" about treatment allocation; (1.5) the treatment and control groups are similar at the start of the trial; (1.6) the only difference between groups is the investigational treatment; (1.7) all relevant outcomes are measured in a standard, valid, and reliable manner; (1.8) what percentage of individuals or groups enrolled in each treatment arm of the study dropped out before the study completion? $(<20 \%$ low risk of bias); (1.9) all participants are analyzed in the randomized groups (often referred to as intention-to-treat analysis); (1.10) when the study is conducted at more than one site, the results are comparable for all sites; and (2.1) how well was the study conducted to minimize bias?

\section{Discussion}

In interpretating the findings, we were careful about generalization due to the number of studies reviewed and their open-access character. However, the results allowed us to answer the guiding research question and identify the educational process characteristics of self-management of health in public healthcare. The results aligned with recent research on the innovation needs of medical and health education programs reported by health institutions and agencies worldwide $[28,30]$. The articles reviewed describe educational programs focused on self-management and self-control to contain disease, especially chronic disease care. These articles suggest that public health education processes continue to prioritize remedial objectives over treatment outcomes for health maintenance.

While public health processes aim to prevent diseases, promote and maintain health and quality of life, the above is interpreted as a call to public health and medical and health education to diversify their objectives and educational strategies for the prevention, promotion, maintenance, and monitoring of population health. Doing so aligns with the recommendations of the World Health Organization (WHO). It invites broadening of the clinical and therapeutic perspective of healthcare and health education through strategies that build frameworks of trust, social support, and learning which respond to the needs of individuals and communities for health and welfare beyond the health-illness binomial [27].

Thus, it seems that health education programs continue to emphasize informative actions on the self-management of diseases, leaving at a low priority the training and monitoring of learning and the appropriation of knowledge and skills for self-care and self-management of health in the daily activities of families and communities [22]. Some recent research initiatives have sought to decenter the functionalist perspective of health 
education programs. However, little research has helped guide the development and implementation of practical health promotion efforts [23]. Most of the findings report educational programs focused on measuring changes in signs and symptoms of disease and, to a lesser extent, assessing behavioral changes to achieve self-management of health. There are few learning assessment products developed in health training.

The findings of this review indicate that health education programs in public health face significant challenges in guaranteeing program access, participation, and permanence and improving the effectiveness of the learning processes. The programs studied mainly address objectives for the self-management of diseases, remaining at the level of health maintenance, and lacking educational processes for disease prevention, promoting integral health, and monitoring people's quality of life and welfare. Some studies emphasized the importance of involving the participants in the design of the educational sessions and using tools, such as dialogue and other interactive methods, to improve participation [28]. Thus, methods, such as peer education, are proposed to strengthen the emotional bonds that alleviate the psychological pressure caused by the health affectation [38]. Other proposals include training and solid supervision of health educators to develop contextual patient-centered approaches. However, the results showed that less than a quarter of medical and health education research describe programs or educational actions oriented to community-based health.

Regarding technological tools, electronic education has become crucial in the information era and, therefore, it is also incorporated in medical and health education processes. Our results identify that technologies have offered robust mechanisms that support the self-management of health and guarantee a lasting educational experience for people, any time and place [30], with new ways to favor self-management processes in public health. Furthermore, tools such as the Internet and technological devices have made it possible to easily and quickly view or generate content (text, images, voice, and video) to support health literacy and self-care, and contribute to the population's quality of life. However, these technologies require digital literacy processes for people with health conditions, professionals, family members, and caregivers.

The findings report that educational processes for self-management of health hold promise for public health intervention when technology supports it. This review suggests recognizing and integrating the transformative possibilities of community education methods coupled with the use of technology. In addition, it is relevant to consider the pedagogical character of health education processes to improve the effectiveness of the programs. To this end, it is essential to strengthen the educational training processes for health professionals and structure evaluation goals for the teaching-learning process in these programs. The assessments should cover content, teaching strategies, appropriation of knowledge, and self-management of health in populations. Concerning technologies in the training processes, their functionality and usability, with regard to achieving the expected learning, should be evaluated.

The findings regarding health education methods of self-care as part of communitybased care and how technological tools are used are fundamental to this review. Consequently, we urge future research to focus on studying the barriers and facilitators that arise when using technological tools as mediators of learning in health education programs, mainly in terms of access to infrastructure, generational gaps, cultural factors, levels of digital literacy, and economic disadvantages [23].

One limitation of this systematic review is language bias, as we only included studies published in English. Therefore, studies published in other languages, such as Chinese and Japanese, were not included in this review. In addition, the review did not include research from grey literature, which could exclude important unpublished pieces produced by non-governmental organizations. Finally, it should be noted that the analyses performed represent a partial view of the phenomenon under study and, therefore, the generalizability of the data is not considered. Despite these limitations, this literature review study 
increased the understanding of self-management health education processes and identified opportunities for improvement.

\section{Conclusions}

This review began with the question, "what are the characteristics of educational processes of self-management of health in public health care?". We identified that the most relevant characteristics respond to objectives focused on self-management of diseases, primarily chronic, and mitigating disease signs and symptoms. There is a focus on remedial education for the maintenance of health that is typical of hospital environments, which, in the public health context, is limited. In this regard, institutions and researchers propose innovative medical and health education processes to improve training and contribute to the prevention, promotion, care, maintenance, and monitoring of integral public health.

The innovative processes highlight social and community-based learning characteristics that involve peers, caregivers, families, and professionals in training actions. In addition, some initiatives highlight socio-emotional characteristics of education and the need for contextual learning in daily life practices. Finally, there are characteristics oriented around using technological tools in the teaching-learning process as an area of opportunity to improve their effectiveness and increase their coverage.

Future research is invited to examine the barriers and facilitators in medical and health education programs using socio-community and technology-enhanced educational strategies. Furthermore, the contributions of innovative processes for public health education toward long-term improvements in self-management of health and diseases should be evaluated. These research needs are especially relevant due to the COVID-19 health crisis because the fundamental medium of knowledge transmission for the formulation and implementation of health education programs, which recognize the health, economic, social, and cultural realities of communities, has become technology.

Author Contributions: Conceptualization, methodology, software, formal analysis, validation, investigation, data curation, writing — original draft preparation, J.A.R.-R., Y.A.O.-A.; writing-review and editing, visualization, supervision, project administration, funding acquisition, L.D.G.-M. All authors have read and agreed to the published version of the manuscript.

Funding: This research received no external funding. The APC was funded by Institute for the Future of Education-Tecnologico de Monterrey.

Acknowledgments: The authors would like to acknowledge the technical support and funding of the Writing Lab, Institute for the Future of Education, Tecnologico de Monterrey, Mexico, in the production of this work. The authors would like to thank Roberto Martínez-Maldonado from Monash University for his contribution in the review process of this article.

Conflicts of Interest: The authors declare no conflict of interest.

\section{References}

1. Martínez, R. Los tratamientos de datos personales en la crisis del COVID-19. Un enfoque desde la salud pública. D. Ley 2020, 9, 30.

2. Correa, F.P.; Ríos, J.M.L.; Berrío, D.P.M. La educación para la salud en la salud pública: Un análisis pedagógico. Promover Vida Salud Paz 2017, 1, 123.

3. Chaturvedi, R.; Desai, C.; Patel, P.; Shah, A.; Dikshit, R.K. An evaluation of the impact of antidiabetic medication on treatment satisfaction and quality of life in patients of diabetes mellitus. Perspect. Clin. Res. 2018, 9, 1-15.

4. De Ridder, D.; Kroese, F.; Evers, C.; Adriaanse, M.; Gillebaart, M. Healthy diet: Health impact, prevalence, correlates, and interventions. Psychol. Health 2017, 32, 907-941. [CrossRef]

5. Zhao, X.; Yu, X.; Zhang, X. The Role of Peer Support Education Model in Management of Glucose and Lipid Levels in Patients with Type 2 Diabetes Mellitus in Chinese Adults. J. Diabetes Res. 2019, 1, 134. [CrossRef]

6. Gagliardino, J.J.; Chantelot, J.M.; Domenger, C.; Ramachandran, A.; Kaddaha, G.; Mbanya, J.C.; Shestakova, M.; Chan, J.; IDMPS Steering Committee. Impact of diabetes education and self-management on the quality of care for people with type 1 diabetes mellitus in the Middle East (the International Diabetes Mellitus Practices Study, IDMPS). Diabetes Res. Clin. Pr. 2019, 147, 29-36. [CrossRef] [PubMed]

7. Ji, H.; Chen, R.; Huang, Y.; Li, W.; Shi, C.; Zhou, J. Effect of simulation education and case management on glycemic control in type 2 diabetes. Diabetes Metab. Res. Rev. 2019, 3, 35. [CrossRef] [PubMed] 
8. Müller, N.; Kloos, C.; Sämann, A.; Wolf, G.; Müller, U.A. Evaluation of a treatment and teaching refresher programme for the optimization of intensified insulin therapy in type 1 diabetes. Patient Educ. Couns. 2013, 1, 108-113. [CrossRef]

9. Muchiri, J.W.; Gericke, G.J.; Rheeder, P. Stakeholders' perceptions of dietary and related self-management challenges and education programme preferences for type 2 diabetes adults. J. Endocrinol. Metab. Diabetes South. Afr. 2019, 24, 1-9. [CrossRef]

10. Brownson, C.A.; Heisler, M. The role of peer support in diabetes care and self-management. Patient Patient Cent. Outcomes Res. 2009, 2, 5-17. [CrossRef]

11. Kugbey, N.; Asante, K.O.; Adulai, K. Illness perception, diabetes knowledge and self-care practices among type-2 diabetes patients: A cross-sectional study. BMC Res. Notes 2017, 10, 1-7. [CrossRef]

12. Cochran, J.; Conn, V.S. Meta-analysis of Quality of Life Outcomes Following Diabetes Self-management Training. Diabetes Educ. 2008, 34, 815. [CrossRef]

13. Michie, S.; Abraham, C.; Whittington, C.; McAteer, J.; Gupta, S. Effective techniques in healthy eating and physical activity interventions: A meta-regression. Health Psychol. 2009, 28, 690. [CrossRef]

14. Garnett, A.; Ploeg, J.; Markle-Reid, M.; Strachan, P.H. Self-management of multiple chronic conditions by community-dwelling older adults: A concept analysis. Sage Open Nurs. 2018, 4, 23. [CrossRef] [PubMed]

15. Varming, A.R.; Torenholt, R.; Andersen, T.H.; Moller, B.L.; Willaing, I. Targeting "hardly reached" people with chronic illness: A feasibility study of a person-centered self-management education approach. Patient Prefer. Adherence 2018, 12, 275-289. [CrossRef] [PubMed]

16. Grajales, F.J.; Sheps, S.; Ho, K.; Novak-Lauscher, H.; Eysenbach, G. Social media: A review and tutorial of applications in medicine and health care. J. Med. Internet Res. 2014, 16, 13. [CrossRef]

17. Israel, B.A.; Coombe, C.M.; Cheezum, R.R.; Schulz, A.J.; McGranaghan, R.J.; Lichtenstein, R. Community-based participatory research: A capacity-building approach for policy advocacy aimed at eliminating health disparities. Am. J. Public Health 2010, 11, 102. [CrossRef] [PubMed]

18. Sandelowsky, H.; Natalishvili, N.; Krakau, I.; Modin, S.; Ställberg, B.; Nager, A. COPD management by Swedish general practitioners-Baseline results of the PRIMAIR study. Scand. J. Prim. Health Care 2018, 36, 5-13. [CrossRef] [PubMed]

19. Siltanen, H.; Aine, T.; Huhtala, H.; Kaunonen, M.; Vasankari, T.; Paavilainen, E. Psychosocial issues need more attention in COPD self-management education. Scand. J. Prim. Health Care 2020, 38, 47-55. [CrossRef]

20. Rasoul, A.M.; Jalali, R.; Abdi, A.; Salari, N.; Rahimi, M.; Mohammad, M. The effect of self-management education through weblogs on the quality of life of diabetic patients. BMC Med. Inf. Decis. Mak. 2019, 19, 120. [CrossRef] [PubMed]

21. Yu, C.H.; Bahniwal, R.; Laupacis, A.; Leung, E.; Orr, M.S.; Straus, S.E. Systematic review and evaluation of web-accessible tools for management of diabetes and related cardiovascular risk factors by patients and healthcare providers. J. Am. Med. Inform. Assoc. 2012, 19, 514. [CrossRef]

22. Senteio, C.R. Investigating the Enduring Impact of a Community-Based Health Education Program to Promote African American Elders' Use of Technology Designed to Support Chronic Disease Self-Management. Geriatrics 2018, 3, 4. [CrossRef] [PubMed]

23. Page, M.J.; McKenzie, J.E.; Bossuyt, P.M.; Boutron, I.; Hoffmann, T.C.; Mulrow, C.D. Updating guidance for reporting systematic reviews: Development of the PRISMA 2020 statement. J. Clin. Epidemiol 2021, 1, 103-115. [CrossRef] [PubMed]

24. Swan, A. Directrices para Políticas de Desarrollo y Promoción del Acceso Abierto; Unesco: Paris, France, 2013.

25. Petrie, J.C.; Grimshaw, J.M.; Bryson, A. The Scottish Intercollegiate Guidelines Network Initiative: Getting validated guidelines into local practice. Health Bull. 1995, 53, 345.

26. Furlan, A.D.; Zhao, J.; Voth, J.; Hassan, S.; Dubin, R.; Stinson, J.N. Evaluation of an innovative tele-education intervention in chronic pain management for primary care clinicians practicing in underserved areas. J. Telemed. Telecare 2019, $25,484-492$. [CrossRef] [PubMed]

27. Manigault, K.R.; Augustine, J.M.; Thurston, M.M. Impact of Student Pharmacists Teaching a Diabetes Self-Management Education and Support Class. Am. J. Pharm. Educ. 2020, 3, 84-90. [CrossRef]

28. Woods, J.; Moorhouse, M.; Knight, L. A descriptive analysis of the role of a WhatsApp clinical discussion group as a forum for continuing medical education in the management of complicated HIV and TB clinical cases in a group of doctors in the Eastern Cape, South Africa. South Afr. J. HIV Med. 2019, 1, 20. [CrossRef]

29. Zimbudzi, E.; Lo, C.; Kerr, P.G.; Zoungas, S. A need-based approach to self-management education for adults with co-morbid diabetes and chronic kidney disease. BMC Nephrol. 2019, 1, 32. [CrossRef] [PubMed]

30. Risica, P.M.; McCarthy, M.; Barry, K.; Oliverio, S.P.; De Groot, A.S. Community clinic-based lifestyle change for prevention of metabolic syndrome: Rationale, design and methods of the 'Vida Sana/healthy life' program. Contemp. Clin. Trials Commun. 2018, 12, 123-128. [CrossRef]

31. McElfish, P.A.; Long, C.R.; Kohler, P.O.; Yeary, K.H.K.; Bursac, Z.; Narcisse, M.-R. Comparative Effectiveness and Maintenance of Diabetes Self-Management Education Interventions for Marshallese Patients With Type 2 Diabetes: A Randomized Controlled Trial. Diabetes Care 2019, 42, 849-858. [CrossRef]

32. Patel, S.; Potter, R.; Matharu, M.; Carnes, D.; Taylor, S.J.C.; Nichols, V. Development of an education and self-management intervention for chronic headache-CHESS trial (Chronic Headache Education and Self-management Study). J. Headache Pain 2019, 1, 20. [CrossRef] [PubMed] 
33. Hailu, F.B.; Moen, A.; Hjortdahl, P. Diabetes Self-Management Education (DSME)—Effect on Knowledge, Self-Care Behavior, and Self-Efficacy Among Type 2 Diabetes Patients in Ethiopia: A Controlled Clinical Trial. Diabetes Metab. Syndr. Obes. Targets 2019, 12, 2489-2499. [CrossRef] [PubMed]

34. Pal, K.; Dack, C.; Ross, J.; Michie, S.; May, C.; Stevenson, F. Digital Health Interventions for Adults With Type 2 Diabetes: Qualitative Study of Patient Perspectives on Diabetes Self-Management Education and Support. J. Med. Internet Res. 2018, 20, e40. [CrossRef]

35. Azami, G.; Soh, K.L.; Sazlina, S.G.; Salmiah, M.S.; Aazami, S.; Mozafari, M. Effect of a Nurse-Led Diabetes Self-Management Education Program on Glycosylated Hemoglobin among Adults with Type 2 Diabetes. J. Diabetes Res. 2018, 11, 180. [CrossRef] [PubMed]

36. Lee, S.-K.; Shin, D.-H.; Kim, Y.-H.; Lee, K.-S. Effect of Diabetes Education Through Pattern Management on Self-Care and Self-Efficacy in Patients with Type 2 Diabetes. Int. J. Environ. Res. Public Health 2019, 16, 18. [CrossRef] [PubMed]

37. Omidi, Z.; Kheirkhah, M.; Abolghasemi, J.; Haghighat, S. Effect of lymphedema self-management group-based education compared with social network-based education on quality of life and fear of cancer recurrence in women with breast cancer: A randomized controlled clinical trial. Qual. Life Res. 2020, 7, 1789-1800. [CrossRef] [PubMed]

38. Farahmand, F.; Khorasani, P.; Shahriari, M. Effectiveness of a self-care education program on hypertension management in older adults discharged from cardiac-internal wards. ARYA Atheroscler. 2019, 15, 44-52. [PubMed]

39. Prevost, V.; Heutte, N.; Leconte, A.; Licaj, I.; Delorme, C.; Clarisse, B. Effectiveness of a therapeutic patient education program in improving cancer pain management: EFFADOL, a stepped-wedge randomized controlled trial. BMC Cancer 2019, 1, 19. [CrossRef] [PubMed]

40. Boels, A.M.; Rutten, G.; Zuithoff, N.; de Wit, A.; Vos, R. Effectiveness of diabetes self-management education via a smartphone application in insulin-treated type 2 diabetes patients-Design of a randomized controlled trial ('TRIGGER study'). BMC Endocr. Disord. 2018, 18, 101. [CrossRef]

41. Zheng, F.; Liu, S.; Liu, Y.; Deng, L. Effects of an Outpatient Diabetes Self-Management Education on Patients with Type 2 Diabetes in China: A Randomized Controlled Trial. J. Diabetes Res. 2019, 1, 68. [CrossRef] [PubMed]

42. Jinnouchi, H.; Matsudaira, K.; Kitamura, A.; Kakihana, H.; Oka, H.; Hayama-Terada, M. Effects of Low-Dose Therapist-Led Self-Exercise Education on the Management of Chronic Low Back Pain: Protocol for a Community-Based, Randomized, 6-Month Parallel-Group Study. Spine Surg. Relat. Res. 2019, 3, 377-384. [CrossRef] [PubMed]

43. Smith, M.L.; Bergeron, C.D.; Ahn, S.; Towne, S.D.; Mingo, C.A.; Robinson, K.T.; Mathis, J.; Meng, L.; Ory, M.G. Engaging the Underrepresented Sex: Male Participation in Chronic Disease Self-Management Education (CDSME) Programs. Am. J. Mens Health 2018, 12, 935-943. [CrossRef] [PubMed]

44. Kennedy, L.E.; Hosig, K.L.; Ju, Y.; Serrano, E.L. Evaluation of a mindfulness-based stress management and nutrition education program for mothers. Cogent Soc. Sci. 2019, 5, 1682928. [CrossRef]

45. Pozza, A.; Osborne, R.H.; Elsworth, G.R.; Gualtieri, G.; Ferretti, F.; Coluccia, A. Evaluation of the Health Education Impact Questionnaire (heiQ), a Self-Management Skill Assessment Tool, in Italian Chronic Patients. Psychol. Res. Behav. Manag. 2020, 13, 459-471. [CrossRef] [PubMed]

46. Sanders, T.; Elliott, J.; Norman, P.; Johnson, B.; Heller, S. Experiences of self-management among young adults with Type 1 diabetes in the context of a structured education programme: A qualitative study. Diabet. Med. 2018, 35, 1531-1537. [CrossRef] [PubMed]

47. Ross, J.; Stevenson, F.A.; Dack, C.; Pal, K.; May, C.R.; Michie, S. Health care professionals' views towards self-management and self-management education for people with type 2 diabetes. BMJ Open 2019, 9, 7. [CrossRef] [PubMed]

48. Carmienke, S.; Baumert, J.; Gabrys, L.; Heise, M.; Frese, T.; Heidemann, C. Participation in structured diabetes mellitus selfmanagement education program and association with lifestyle behavior: Results from a population-based study. BMJ Open Diabetes Res. Care 2020, 8, e001066. [CrossRef]

49. Pratt, K.J.; Jalilvand, A.; Needleman, B.; Urse, K.; Ferriby, M.; Noria, S. Postoperative outcomes based on patient participation in a presurgery education and weight management program. Surg. Obes. Relat. Dis. 2018, 14, 1714-1723. [CrossRef]

50. Jönsson, T.; Eek, F.; Dell'Isola, A.; Dahlberg, L.E.; Ekvall Hansson, E. The Better Management of Patients with Osteoarthritis Program: Outcomes after evidence-based education and exercise delivered nationwide in Sweden. PLoS ONE 2019, 14, 109. [CrossRef]

51. Ridsdale, L.; McKinlay, A.; Wojewodka, G.; Robinson, E.J.; Mosweu, I.; Feehan, S.J.; Noble, A.J.; Morgan, M.; Taylor, S.J.; McCrone, P.; et al. Self-Management education for adults with poorly controlled epILEpsy [SMILE (UK)]: A randomized controlled trial. Health Technol. Assess. 2018, 22, 1-142. [CrossRef] [PubMed]

52. Chang, Y.-Y.; Dai, Y.-T. The efficacy of a flipping education program on improving self-management in patients with chronic obstructive pulmonary disease: A randomized controlled trial. Int. J. Chron. Obs. Pulmon. Dis. 2019, 14, 1239-1250. [CrossRef] [PubMed]

53. Davies, M.J.; Kristunas, C.A.; Alshreef, A.; Dixon, S.; Eborall, H.; Glab, A. The impact of an intervention to increase uptake to structured self-management education for people with type 2 diabetes mellitus in primary care (the embedding package), compared to usual care, on glycaemic control: Study protocol for a mixed-methods study. BMC Fam. Pr. 2019, $20,1-15$.

54. Vandenbosch, J.; den Broucke, S.; Schinckus, L.; Schwarz, P.; Doyle, G.; Pelikan, J.; Muller, I.; Levin-Zamir, D.; Schillinger, D.; Chang, P.; et al. The impact of health literacy on diabetes self-management education. Health Educ. J. 2018, 77, 349-362. [CrossRef] 
55. Liu, X.-L.; Wu, C.-J.; Willis, K.; Shi, Y.; Johnson, M. The impact of inpatient education on self-management for patients with acute coronary syndrome and type 2 diabetes mellitus: A cross-sectional study in China. Health Educ. Res. 2018, 33, 389-401. [CrossRef] [PubMed]

56. Preechasuk, L.; Sriussadaporn, P.; Likitmaskul, S. The obstacles to diabetes self-management education and support from healthcare professionals' perspectives: A nationwide survey. Diabetes Metab. Syndr. Obes. Targets 2019, 12, 717-727. [CrossRef] [PubMed]

57. Bourbeau, J.; Farias, R.; Li, P.Z.; Gauthier, G.; Battisti, L.; Chabot, V.; Beauchesne, M.-F.; Villeneuve, D.; Côté, P.; Boulet, L.-P. The Quebec Respiratory Health Education Network: Integrating a model of self-management education in COPD primary care. Chron. Respir. Dis. 2018, 15, 103-113. [CrossRef] 